\title{
Pola asuh pada anak gangguan pemusatan perhatian dan hiperaktivitas di kota Manado
}

\author{
${ }^{1}$ Novita Kaunang \\ ${ }^{2}$ Herdy Munayang \\ ${ }^{2}$ Theresia M. D. Kaunang
}

\author{
${ }^{1}$ Kandidat Skripsi Fakultas Kedokteran Universitas Sam Ratulangi Manado \\ ${ }^{2}$ Bagian Psikiatri Fakultas Kedokteran Universitas Sam Ratulangi Manado \\ Email: novita.kaunang12124@yahoo.com
}

\begin{abstract}
Children with attention deficit and hyperactivity disorder (ADHD) are children who have excessive activities and can not concentrate well. Worldwide study showed a quite high prevalence of ADHD as many as $5.29 \%$. Parenting style is very influential on a child's mental and development, therefore, parents who are the child's family have to be patient and serious in taking care of their child. This study aimed to obtain the parenting style of children with ADHD in Manado. This was a descriptive study with a cross-sectional design. Assessment of parenting style types was obtained by using parenting style questionnaire. The results showed that there were 210 parents as respondents. Data were analyzed with a univariate analysis. Democratic parenting style was mostly applied by the parents as many as $95,24 \%$, followed by permissive style $3.34 \%$ and authoritarian style $1.42 \%$.
\end{abstract}

Keywords: ADHD, children, parenting style

\begin{abstract}
Abstrak: Anak dengan gangguan pemusatan perhatian dan hiperaktivitas (GPPH) adalah anak yang beraktivitas berlebihan dan tidak dapat berkonsentrasi dengan baik. Prevalensi GPPH di seluruh dunia cukup tinggi yaitu sebesar 5,29\%. Pola asuh orang tua sangat berpengaruh pada mental dan perkembangan anak sehingga orang tua yang merupakan keluarga perlu dengan sabar dan tekun mengasuh anaknya. Penelitian ini bertyujuan untuk mendapatkan gambaran pola asuh orang tua dengan anak GPPH di kota Manado. Jenis penelitian ini deskriptif dengan desain potong lintang. Penilaian jenis pola asuh orang tua menggunakan angket pola asuh. Hasil penelitian mendapatkan responden sebanyak 210 orang tua dengan anak GPPH. Pola asuh demokratis paling banyak diterapkan oleh orang tua sebesar 95,24\%, diikutipola asuh permisif 3,34\% sedangkan pola asuh yang paling jarang diterapkan ialah otoriter sebanyak $1,42 \%$.
\end{abstract}

Kata kunci: GPPH, anak, pola asuh

Pola asuh orang tua sangat berpengaruh pada mental dan perkembangan anak sehingga orang tua yang merupakan bagian dari keluarga perlu dengan sabar dan tekun mengasuh anaknya. Pendidikan anak mengenai hal-hal baik sebagai pedoman hidup harus didapatkan pertama kali dari keluarga mereka sendiri. Sayangnya ada sejumlah anak tidak mendapatkan hal tersebut sehingga mereka harus belajar dari luar keluarga antara lain: tetangga, teman bermain, dan guru sekolah.

Hurlock membagi pola asuh atas tiga jenis yaitu: demokratis, otoriter, dan permisif. Pada keluarga dengan pola asuh otoriter, anak-anaknya tidak memiliki kebebasan untuk menentukan keputusan, bahkan untuk dirinya sendiri karena semua keputusan berada di tangan orang tua dan dibuat oleh orang tua sedangkan anak harus 
mematuhinya tanpa ada kesempatan untuk menolak ataupun mengemukakan pendapat. Ciri khas pola asuh ini antara lain ialah kekuasaan orang tua dominan malah boleh dikatakan mutlak. Anak yang tidak mematuhi orang tua akan mendapatkan hukuman berat, pendapat anak tidak didengarkan sehingga anak tidak memiliki eksistensi di rumah, tingkah laku anak dikontrol dengan sangat ketat. Pola asuh demokratis menjunjung keterbukaan, pengakuan terhadap pendapat anak, dan kerjasama. Anak-anak diberi kebebasan, tapi kebebasan yang bisa dipertanggungjawabkan. Anak diberi kepercayaan untuk mandiri tapi tetap dipantau. Ciri yang kental dari pola asuh ini ialah adanya diskusi antara anak dan orang tua. Kerja sama berjalan dengan baik antara anak dan orang tua. Anak diakui eksistensinya. Kebebasan berekspresi diberikan pada anak dengan tetap berada di bawah pengawasan orang tua. Pada pola asuh permisif, orang tua memberikan kebebasan penuh kepada anak. Cirinya, orang tua bersikap longgar, tidak terlalu memberi bimbingan dan kontrol, perhatian pun terkesan kurang. Kendali anak sepenuhnya terdapat pada anak itu sendiri. ${ }^{1}$

Anak dengan gangguan pemusatan perhatian dan hiperaktivitas (GPPH) adalah anak yang beraktivitas berlebihan dan tidak dapat berkonsentrasi dengan baik. Gangguan pemusatan perhatian dan hiperaktivitas bukan kondisi tunggal tetapi banyak kondisi yang memengaruhi presentasi klinis. Kondisi lain yang dapat memengaruhi antara lain: cedera kepala, gangguan intelektual, kerusakan lobus frontal, psikosis, kecemasan yang parah, dan depresi. Setiap kondisi yang terjadi pada anak memerlukan perawatan yang sangat berbeda. ${ }^{2}$

Belum ditemukan penyebab pasti terjadinya GPPH. Dalam suatu penelitian, faktor genetik paling banyak ditemukan. Sekitar 76-91\% anak GPPH memiliki anggota keluarga yang mengalami GPPH juga. Prevalensi GPPH di seluruh dunia 5,29\% sedangkan di Afrika bervariasi antara 5,4\% dan 8,7\%; di antara anak-anak sekolah terdapat $1,5 \%$, dan di antara anakanak dari masyarakat umum yang memiliki kelainan otak organik 45,5\%-100\%. ${ }^{3-5}$

Meskipun etiologi GPPH belum ditentukan, terdapat konsensus yang berkembang bahwa kondisi melibatkan disfungsi secara fungsional dan anatomi di korteks frontal otak dan segmen ganglia basalis dari sirkuit basal ganglia kortiko talamo. Daerah ini mendukung regulasi sumber daya atensi, pemrograman perilaku motorik yang kompleks dan menanggapi sesuatu. Teori yang melibatkan daerah ini telah diperiksa secara serial yang melibatkan penelitian neurobiologik manusia yang sehat, manusia dengan GPPH, dan model hewan. Castellanos dan Swanson telah menggambarkan kompleksitas GPPH ini, keragaman teoritis, dan banyak pertanyaan yang belum diselesaikan. Gejala GPPH ialah multidimensional yang menunjukkan interaksi sistem neuroanatoml dan neurokimia. Bukti saat ini untuk faktor neurobiologik menunjukkan bahwa faktor genetik dan neurokimia berperan. ${ }^{6}$

Prevalensi GPPH di Indonesia di Kecamatan Padang Timur sebesar 8\%. Anak laki-laki lebih banyak daripada perempuan dengan perbandingan 2:1 dan pada kategori usia 11-13 tahun sekitar berada pada tingkatan kelas 5. Di Kota Manado pada tahun 2013 ditemukan prevalensi GPPH berjumlah 311 murid dari 10 sekolah dan persentase GPPH tertinggi pada usia 6 tahun sebanyak 57 siswa (27,1\%), berjenis kelamin laki-laki (18,1\%). Berdasarkan tingkat keparahan, GPPH derajat ringan sebanyak 43 anak (20,5\%), GPPH derajat sedang sebanyak 11 anak (5,2\%), dan GPPH derajat berat sebanyak 9 anak (4,3\%). Dalam penelitiannya juga didapatkan hubungan bermakna antara gangguan pemusatan perhatian dan hiperaktifitas dengan prestasi belajar yakni 38 anak laki-laki dan 30 anak perempuan; 68 anak ini mengalami kesulitan dalam belajar sehingga mengganggu prestasi mereka. ${ }^{7,8}$

Penelitian ini bertujuan untuk mendapatkan pola asuh pada anak GPPH yang berada di kota Manado. 


\section{METODE PENELITIAN}

Jenis penelitian ini ialah deskriptifkuantitatif untuk menilai pola asuh orang tua pada anak GPPH yang ada di 20 sekolah dasar (SD) di Kota Manado dengan desain penelitian potong lintang. Penelitian ini berlangsung selama bulan November 2015-Januari 2016. Kriteria inklusi ialah orang tua yang memiliki anak dengan GPPH usia 6-12 tahun; orang tua atau pengasuh yang bersedia mengisi angket; dan pengasuh yang bekerja sudah lebih dari 6 bulan. Angket pola asuh orang tua berjumlah 30 item pernyataan, yang disusun oleh Jayanti berdasarkan teori Hurlock (1999) dan sedikit dimodifikasi oleh penulis untuk mengadaptasi keadaan responden yang merupakan orang tua atau pengasuh di Kota Manado.

Data yang telah terkumpul melalui angket diolah menggunankan analisis univariat. Karakteristik data meliputi frekuensi dan persentase dari variabel yang diteliti kemudian data ditabulasi.

\section{HASIL PENELITIAN}

Berdasarkan hasil skrining anak GPPH yang dilakukan di 20 sekolah dasar yang berada di Kota Manado selama bulan Desember 2015 - Januari 2016, didapatkan 611 anak dengan GPPH. Terdapat 210 orang tua dengan anak GPPH yang bersedia menjadi responden penelitian.

Karakteristik responden orang tua atau pengasuh anak dengan GPPH yaitu berdasarkan jenis pola asuh, pekerjaan, dan tingkat pendidikan.

\section{Jenis pola asuh}

Tabel 1. Distribusi jenis pola asuh yang diterapkan

\begin{tabular}{ccc}
\hline $\begin{array}{c}\text { Jenis } \\
\text { pola asuh }\end{array}$ & Frekuensi & $\mathbf{( \% )}$ \\
\hline Otoriter & 3 & 1,42 \\
Demokratis & 200 & 95,24 \\
Permisif & 7 & 3,34 \\
Total & 210 & 100 \\
\hline
\end{tabular}

Tabel 1 memperlihatkan pola asuh yang paling banyak diterapkan pada anak dengan GPPH ialah pola asuh demokratis, yaitu sebanyak 200 orang $(95,24 \%)$ diikuti pola asuh permisif 3 orang $(1,42 \%)$ dan otoriter 3 orang $(1,42 \%)$.

\section{Pendidikan terakhir}

Tabel 2 menampilkan pendidikan orang tua dengan anak GPPH yang terbanyak yaitu SMA/SMK (103 orang) dengan jenis pola asuh terbanyak ialah demokratis $(45,23 \%)$.

Tabel 2. Distribusi pola asuh berdasarkan pendidikan terakhir

\begin{tabular}{ccccccc}
\hline $\begin{array}{c}\text { Pendidikan } \\
\text { Terakhir }\end{array}$ & Otoriter & $\begin{array}{c}\text { Pola asuh } \\
\text { Demokratis }\end{array}$ & Permisif \\
& & & & & & \\
& F & \% & F & \% & F & \% \\
\cline { 2 - 7 } SD & 0 & 0 & 9 & 4,28 & 0 & 0 \\
SMP & 0 & 0 & 30 & 14,28 & 2 & 0,95 \\
SMA/SMK & 3 & 1,42 & 95 & 45,23 & 5 & 2,38 \\
$\begin{array}{c}\text { Perguruan } \\
\text { tinggi }\end{array}$ & 0 & 0 & 66 & 31,42 & 0 & 0 \\
\hline
\end{tabular}

\section{Pekerjaan}

Tabel 3. Distribusi pola asuh berdasarkan pekerjaan

\begin{tabular}{ccccccc}
\hline \multirow{2}{*}{ Pekerjaan } & \multicolumn{7}{c}{ Pola asuh } \\
& \multicolumn{2}{c}{ Otoriter } & \multicolumn{2}{c}{ Demokratis } & \multicolumn{2}{c}{ Permisif } \\
\cline { 2 - 7 } & $\mathbf{F}$ & $\mathbf{\%}$ & $\mathbf{F}$ & $\mathbf{\%}$ & $\mathbf{F}$ & $\mathbf{\%}$ \\
\hline Swasta & 0 & 0 & 34 & 16,19 & 1 & 0,47 \\
Pendeta & 0 & 0 & 4 & 1,90 & 0 & 0 \\
PNS & 0 & 0 & 22 & 10,47 & 1 & 0,47 \\
Wiraswqasta & 1 & 0,47 & 17 & 8,09 & 1 & 0,47 \\
Karyawan & 0 & 0 & 5 & 2,38 & 0 & 0 \\
Polisi & 0 & 0 & 1 & 0,47 & 0 & 0 \\
IRT & 2 & 0,95 & 91 & 43,33 & 3 & 1,42 \\
Pengacara & 0 & 0 & 1 & 0,47 & 0 & 0 \\
Buruh & 0 & 0 & 6 & 2,85 & 0 & 0 \\
Ojek & 0 & 0 & 3 & 1,42 & 0 & 0 \\
Pedagang & 0 & 0 & 2 & 0,95 & 1 & 0,47 \\
Pegawai & 0 & 0 & 3 & 1,42 & 0 & 0 \\
Nelayan & 0 & 0 & 3 & 1,42 & 0 & 0 \\
Pensiunan & 0 & 0 & 2 & 0,95 & 0 & 0 \\
Guru & 0 & 0 & 4 & 1,90 & 0 & 0 \\
Sopir & 0 & 0 & 2 & 0,95 & 0 & 0 \\
\hline
\end{tabular}

Tabel 3 menampilkan bahwa pekerjaan terbanyak orang tua yang mengasuh anak 
GPPH yaitu ibu rumah tangga (IRT) dengan jumlah 88 responden dengan jenis pola asuh terbanyak ialah demokratis $(43,33 \%)$, diikuti pola asuh otoriter (0,95\%) dan permisif $(1,42 \%)$.

\section{BAHASAN}

Berdasarkan hasil penelitian terdapat 210 responden penelitian yang memenuhi kriteria inklusi. Jenis pola asuh pada anak dengan GPPH terbanyak yaitu jenis pola asuh demokratis sebanyak 194 orang (95,24\%), diikuti oleh permisif 7 orang $(3,34 \%)$ dan otoriter 3 orang $(1,42 \%)$. Penelitian di Iran yang membandingkan gaya pengasuhan anak GPPH dan normal mendapatkan bentuk pola asuh permisif pada anak GPPH sangat sedikit dan yang terbanyak ialah pola asuh demokratis. Hal tersebut mungkin dipengaruhi oleh usia dan pendidikan orang tua. Jenis pola asuh dapat memperberat gejala dari anak dengan $\mathrm{GPPH}^{9}$

Berbeda dengan di Manado, pola asuh demokratis paling banyak diterapkan. Hal ini menunjukan bahwa orang tua memiliki sikap yang tegas dan tidak memanjakan anak, namun terdapat interaksi yang baik antara anak dan orang tua. Penelitian yang dilakukan di Pakistan menunjukkan bahwa pola asuh otoriter dan permisif memiliki hubungan bermakna dengan perilaku pemberontak pada anak GPPH, baik terhadap orang tua maupun guru di sekolah. ${ }^{10}$ Hal ini terjadi karena pola asuh otoriter membuat anak harus dengan pasti mengikuti perintah orang tua sedangkan orang tua tidak menerima alasan anak untuk tidak mengikuti perintah. Pada pola asuh permisif, orang tua selalu memenuhi perintah anak tanpa mengetahui dampak yang akan terjadi. Menjaga dan melindungi anak ialah kewajiban utama dari orang tua. Itulah sebabnya orang tua dengan pola asuh permisif biasanya mengalami percekcokan dengan anak sebelum memenuhi kemauan anak. Hal ini yang dapat membuat menjadi anak pemberontak.

Berdasarkan hasil yang diperoleh dari data demografi, distribusi pendidikan terakhir berdasarkan pola asuh terbanyak yaitu SMA/SMK (103 orang) dengan gaya pengasuhan demokratis. Penelitian yang dilakukan di Isfahan, Iran menunjukkan tingkat pendidikan SMA memiliki pola asuh permisif yang lebih banyak dibandingkan dengan yang lain. Hal tersebut mungkin terjadi karena ibu dan anak perempuan disana memiliki hubungan yang dekat dan tanpa aturan yang mengontrol. Orang tua dengan tingkat pendidikan terakhir SMA dapat dikatakan pendidikannya cukup memadai. Orang tua berpendidikan rendah mungkin memperlakukan anak dengan ADHD lebih agresif, sehingga menyebabkan peningkatan gejala ADHD. ${ }^{11}$

Hasil kedua penelitian ini menunjukkan bahwa orang tua perlu mempelajari dan mengerti bagaimana pola asuh yang tepat untuk diterapkan bagi anak GPPH. Seorang pengasuh dapat saja memiliki tingkat pendidikan yang rendah, namun orang tua kandung dari anak GPPH memiliki tingkat pendidikan yang tinggi. Diperlukan interaksi antara orang tua kandung dan pengasuh dalam memberi penjelasan atau pengetahuan yang baik dalam mendidik anak dengan GPPH.

Data demografi penelitian ini memperlihatkan jenis pekerjaan responden terbanyak yaitu IRT dengan jumlah 96 orang. Gaya pengasuhan demokratis, otoriter, dan permisif ditemukan pada orang tua dengan pekerjaan ibu rumah tangga tetapi mayoritas ialah gaya pengasuhan demokratis. Tingkat pekerjaan IRT di Manado terbanyak ialah mengurus rumah tangga. Penelitian yang dilakukan di Saudi Arabia melaporkan bahwa tidak semua IRT dengan anak GPPH memiliki gaya pengasuhan yang baik. Pekerjaan IRT juga dapat menggunakan pola asuh permisif ataupun otoriter. Faktor seperti pendidikan orang tua berpengaruh dalam pengasuhan anak. Pekerjaan tidak mencerminkan pendidikan orang tua sehingga diperlukan penelitian lebih lanjut mengenai peran pekerjaan. ${ }^{12}$ Penelitian di Kanada menunjukkan perilaku anak terhadap orang tua dipengaruhi oleh pendapatan dan jenis pekerjaan orang tua 
terutama ayah mereka dan tentunya dengan pola asuh yang diterapkan. Penerapan pola asuh yang bersifat menghukum, menolak, otoriter dan pekerjaan dari orang tua yang bersifat negatif, membuat anak menjadi malu untuk bergaul dan bersikap berlebihan. $^{13}$

Bahasan di atas menunjukkan bahwa pola asuh yang tepat sangat penting diterapkan karena perlu ada interaksi yang baik antara anak dan orang tua. Bahkan pekerjaan yang dimiliki orang tua harus dapat membuat anak bangga dan bersyukur memiliki orang tua yang dapat mengasuh dengan baik walaupun perkerjaan yang ditekuni sangat sulit untuk mendapat keuntungan lebih.

\section{SARAN}

1. Penelitian ke depan sekiranya memiliki jumlah sampel yang lebih banyak, sehingga data lebih akurat. Dalam penelitian ini banyak orang tua yang tidak mengembalikan angket, sehingga dari 611 anak yang terdeteksi GPPH, yang memenuhi kriteria inklusi hanya sebanyak 211 responden.

2. Bagi orang tua, sikap anak yang nakal di usia SD perlu diwaspadai. Jika anak telah terdeteksi dengan GPPH, kiranya lebih baik mengunakan pola asuh demokratis. Orang tua harus lebih bijaksana dan tegas dan diperlukan interaksi yang baik antara anak dan orang tua.

3. Guru di sekolah perlu memahami gejala GPPH dan dapat memberi rujukan pada orang tua agar memeriksakan anak mereka ke dokter.

4. Diperlukan perhatian dari pemerintah terhadap orang tua yang memiliki anak yang terdeteksi GPPH. Perlu dilakukan seminar atau sosialisasi dan bantuan biaya pengobatan bagi orang tua yang tidak mampu sehingga orang tua dapat menggunakan pola asuh yang tepat, dan anak GPPH dapat terhindar dari kejadian buruk yang tidak diharapkan orang tua serta dapat memperoleh masa depan yang lebih baik.

\section{DAFTAR PUSTAKA}

1. Suryani Y. Mendidik Anak dengan AlQuran sejak Janin. Jakarta: Grasindo, 2011; p. 53-4.

2. Lask B, Taylor S, Nunn KP. Practical Child Psychiatry: The clinician's guide. BMJ Books, 2003; p. 46.

3. Li D, Sham PC, Owen MJ, He L. Metaanalysis shows significant association between dopamine system genes and attention deficit hyperactivity disorder (ADHD). Human Molecular Genetics. 2006;15:2276-84

4. Polanczyk G, Lima MSD, Horta BL, Biederman J, Rohde LA. The worldwide prevalence of ADHD: a systematic review and metaregression analysis. Am J Psychiatry. 2007; 164;942-8.

5. Bakare MO. Attention deficit hyperactivity symptoms and disorder (ADHD) among African children: a review of epidemiology and co-morbidities. African Journal Psychiatry. 2012; 15:358-61.

6. Greenhill LL, Hechtman LI. Attentiondeficit/hiperactivity disorder. In: Comprehensive Textbook of Psychiatry (9th ed). Philadelphia: Lippincot William \& Wilkins, 2009; p. 3561-2.

7. Novriana DE, Yanis A, Masri $M$. Prevalensi gangguan pemusatan perhatian dan hiperaktivitas pada siswa dan siswi Sekolah Dasar Negeri Kecamatan Padang Timur Kota Padang tahun 2013. Jurnal Fakultas Kesehatan Andalas. 2014;3(2):141-6.

8. Lalusu R, Kaunang $\mathbf{T}$, Kandou $\mathbf{J}$. Hubungan gangguan pemusatan perhatian dan hiperaktivitas dengan prestasi belajar pada anak SD kelas 1 di Kecamatan Wenang Kota Manado. Jurnal e-CliniC. 2014;2(1):1-5.

9. Moghaddam MF, Assareh M, Heidaripoor A, Rad AE, Pishjoo M. The study comparing parenting styles of children with ADHD and normal children. Archives of Psychiatry and Psychotherapy. 2013;4:45-9.

10.Sheraz A, Najam N. Parenting styles, parenting practices and ADHD: predicting oppositional defiant behaviour in school and home setting. 
Kaunang, Munayang, Kaunang: Pola asuh pada...

VFAST Transactions on Education and Social Sciences. 2015;8(1):7-18.

11.Ashraf K, Soheila S, Sharareh DE, Elahe

A. Relationship between mothers' parenting style in female students of guidance schools in Isfahan and background factors. IJNMR. 2008;13:118.

12.Hamed HA, Taha AZ, Sabra AA, Bella

H. Attention Deficit Hyperactivity
Disorder (ADHD): is it a health problem among male primary school children. Bahrain Med Bull. 2008;30:6.

13.Stewart W, Barling J. Fathers' work experience effect children's behaviors via job-related affect and parenting behavior. J Organ Behav. 1996;(17);221-32. 